\title{
Extracellular hemoglobin and environmental stress tolerance in Chironomus larvae
}

\author{
Bimalendu B. NATH*
}

Stress Biology Research Laboratory, Department of Zoology, Savitribai Phule Pune University, Pune 411007, India

*Corresponding author: bbnath@gmail.com

\begin{abstract}
Hemoglobin $(\mathrm{Hb})$ is one of the most common conserved molecules found in organisms belonging to all major kingdoms of life. Chironomid midge larvae are unique among the invertebrates being the only free-living group of organisms possessing extracellular hemoglobins (Hbs) in monomeric and dimeric forms floating in their hemolymph. Remarkable ability of individual species of chironomid midges to tolerate wide range of environmental stressors prevailing in their respective ecosystems has enabled chironomids to sustain as one of the most widely distributed insects in the world. Ability of different Chironomus spp to thrive under extreme hypoxic conditions as well as in the presence of chemical pollution made chironomid midges an efficient model system to assess the effect of environmental stress in different freshwater ecosystems. The modulation of Hb concentration has been found to be a function of different type of abiotic stressors and thus $\mathrm{Hb}$ of chironomid midges $(\mathrm{Ch}-\mathrm{Hb})$ has attracted the attention as a potential biomarker for environmental biomonitoring. Large body of literature on $\mathrm{Ch}-\mathrm{Hb}$ accumulated mainly during sixties to eighties of twentieth century has enriched our understanding of its physiological, developmental and biochemical features. Empirical as well as in-silico studies carried out in recent years provided insights into many structure-function relationships of Ch$\mathrm{Hb}$. However, for the last few decades, majority of the studies were carried out to project and validate $\mathrm{Ch}-\mathrm{Hb}$ as potential bioindicator for evaluating toxicants, chemical pollutants and environmental gradients of dissolved oxygen concentration. In this review, historical development of the subject has been compiled with notes on future implications of contemporary studies on $\mathrm{Ch}-\mathrm{Hb}$.
\end{abstract}

Key words: Chironomus; chironomid midge; extracellular hemoglobin; stress tolerance; hypoxia; biomarker; biomonitoring freshwater ecosystem.

Received: March 2018. Accepted: October 2018.

This paper was presented at the 20 $0^{\text {th }}$ International Symposium on Chironomidae, Trento, Italy, 2-8 July 2017.

Session: Autecology and Physiology.

\section{INTRODUCTION}

Hemogoblin $(\mathrm{Hb})$ happens to be the most studied of all proteins. Occurrence of hemoglobins (Hbs) across living kingdoms, its diversity amongst various taxa, and its complex developmental regulation makes Hbs a fascinating family of proteins and genes (Hardison, 1998; Vinogradov et al., 2005). Hbs are ubiquitous among all the vertebrates known till date with little variation in the quaternary structure. On the other hand, extracellular Hbs of invertebrates are sporadic and whenever present, the Hbs exhibit large scale structural heterogeneity (Vinogradov, 1985; Weber and Vinogradov, 2001) making these globins interesting and intriguing from the physiological, ecological and evolutionary context. Comparative information on invertebrate globins is very less compared to wealth of literature available for vertebrate globins. In the past, red body fluid in the invertebrates was described as cruorine, erythrocruorin and also as hemerythrin or hemoglobin depending on the time of publication and organisms (Terwilliger, 1980). The body fluid of many invertebrates is characterized by presence of respiratory pigments other than $\mathrm{Hb}$, which are reviewed by Weber and Vinogradov (2001). Among insects, Hbs have been fully characterized till date only from Chironomus thummi thummi, Drosophila melanogaster and the larvae of the parasite botfly Gasterophilus intestinalis. Amongst these, Chironomus $\mathrm{Hbs}$ are extracellular, freely circulating in the hemolymph, while the Hbs of Drosophila and Gasterophilus are intracellular (Osmulski and Leyko, 1986; Pesce et al., 2005; Burmester et al., 2006).

Chironomid non-biting midges comprise one of the largest insect families (Insecta: Order Diptera) inhabiting diverse freshwater ecosystem across the world. Lifecycle of the non-biting midges consists of aquatic egg, larval, pupal and terrestrial adult stages. Aquatic larval stage is the longest and these larvae are conspicuous in any freshwater ecosystem due to the presence of high concentration of $\mathrm{Hb}$ which renders them a bright coloration and hence the genesis of its popular name as 'blood worms' (Oliver 1971; Pinder 1986; Armitage et al., 1995; Ferrington, 2008). Chironomid midge hemoglobin $(\mathrm{Ch}-\mathrm{Hb})$ attracted attention of molecular evolutionary biologists with Antoine and Niessing's publication (1984) 
of intron-less globin genes in C. thummi thummi. The lack of intron could not be explained by convergent evolution of vertebrate and Chironomus globins. One plausible hypothesis could be existence of an ancestral globin gene with three (or more) introns and during the divergence of the Kingdoms Plantae and Animalia, the plants retained three introns (in Leghemoglobins) and later during the divergence of vertebrates and invertebrates, all vertebrate animals retained few introns while amongst invertebrates, the chironomid midges lost all introns (Hardison, 1998). This postulation became little complicated when Hankeln et al. (1997) reported presence as well as absence of central introns in many European and Australian species of Chironomus. The speculated insertion by gene conversion like mechanism indicated transposition type events leading to $\mathrm{Hb}$ gene polymorphism found in extant Chironomus spp. (Gruhl et al. 2000). However, phylogenetic analyses based on amino acid sequences of $\mathrm{Hb}$ variants as well as nucleotide sequences of corresponding $\mathrm{Hb}$ genes indicated that evolution of chironomid $\mathrm{Hb}(\mathrm{Ch}-\mathrm{Hb})$ genes arose through series of successive gene duplication followed by diversification (Hankeln et al., 1998). It is now a widely accepted view that the divergence of $\mathrm{Ch}-\mathrm{Hb}$ genes occurred from a monometic globin lineage 270-300 million years ago (Goodman et al., 1988). Number of globin genes coding for extracellular hemoglobins in C. thummi thummi was estimated to be 27 , although other studies in $C$. tentans, the number exceeded over 40 which is till date the largest $\mathrm{Hb}$ gene family reported in any organism (Hankeln et al., 1998 and references therein).

In the past, mode of larval life and ecological parameters were linked with properties of $\mathrm{Hb}$ in different species of Chironomus. Among these, intrinsic factors like hormones and extrinsic factors like hypoxia and presence of toxicants were the major causative factors implicated with the modulation of $\mathrm{Hb}$ concentration and corresponding gene expression (Osmulski and Leyko, 1986). Environmental biologists have been using different stages of Chironomus as freshwater biomonitoring agent for the last three decades or so (Choi, 2004). Morphological deformities have been used as endpoints to assess the impact of pollutants/ toxicants including radionuclide, heavy metals and other stressors (Ingersoll and Nelson, 1990; Clarke, 1993; Armitage et al., 1995; Hamalainen, 1999; Dias et al., 2008). Salivary gland polytene chromosome of chironomid larval midges served as an excellent cytogenetic tool as indicators of metalgenotoxicity and other stressors (Nath and Lakhotia, 1989; Martin, 1996; Bernabo et al., 2011; Michailova et al., 2011, 2012; Michailova and Petrova, 2015; Lencioni et al., 2016). Additionally, stress proteins like Hsp70 (Nath and Lakhotia, 1989; Karouna-Renier and Zehr, 1999; Morales et al., 2011; Datkhile et al., 2011) and stress-responsive metabolites (Thorat et al., 2017) of chironomid larvae were also used as indicator biomolecules for assessing environmental stress. However, in this review, I shall focus only chironomid $\mathrm{Hb}$, as and when attempts were made to establish $\mathrm{Hb}$ as bioindicator of environmental stress.

\section{HEMOGLOBIN IN CHIRONOMID MIDGES}

\section{Developmental features}

Heterogeneity and ontogenic difference of Hbs among different larval stages were first reported by Manwell (1966). Thompson and English (1966) found abundance of larval hemoglobin towards later stages of larval development and later on, an elaborate account of ontogenic changes in $\mathrm{Hb}$ synthesis in C. tentans was published by English (1969). Appearance of $\mathrm{Hb}$ could be first noticed during the second instar larvae and the $\mathrm{Hb}$ content reached up to $90 \%$ of the total hemolymph protein by the time larvae moved to fourth instar of development. Bergtrom et al. (1976) demonstrated larval fat body as the major site of $\mathrm{Hb}$ synthesis and secretion. Radiolabelling studies also confirmed that the biosynthesis of both heme and globin could take place in the larval fat body. The seminal study of Bergtrom and his group was the first demonstration of $\mathrm{Hb}$ synthesis using organ culture in any invertebrate. Tissue specificity of $\mathrm{Hb}$ synthesis in the larval sub-epidermal fat body of $C$. thummi was further confirmed by Vafopoulou-Mandalos and Laufer (1983) using autoradiographic technique. Hbs are exported to hemolymph from the fat body cells by means of $\mathrm{N}$ terminal signal peptides. By the time the metamorphosis concludes at the adult stage, more than $95 \%$ of the $\mathrm{Hb}$ can be found as degraded. Using meticulously designed experiments with radioactive tracers $\left({ }^{59} \mathrm{Fe}-\right.$ labelled $\left.\mathrm{Hb}\right)$ Schin et al. (1974) demonstrated gradual decline of $\mathrm{Hb}$ concentration post-fourth instar larval period till the pharate adult stage in $C$. pallidivitatus. Hbs are degraded in the Malpighian tubules (Jarial 1988). The mature adults were hardly found to possess any $\mathrm{Hb}$ which underwent degradation represented by increment in bile pigments, identified as bililatrenes (Schin et al., 1974). Detailed studies, especially during 80's decade of the last century, established $\mathrm{Ch}-\mathrm{Hbs}$ as potent allergens (Trewitt and Bergtrom ,1981; Cranston, 1988; Baur et al., 1986). Other studies implicated degraded products of $\mathrm{Hb}$ are responsible for the high prevalence of sensitization producing conjunctivitis, rhinitis and asthma by inhalation. IgE mediated hypersensitivity was reported among handlers of fish food in their workplace because chironomid midges are popularly used as nutrients in fish aquarium (Ballesteros et al., 2006).

Molting in holometabolous insects are regulated by 
hormones like ecdysones and juvenile hormones. On the other hand, a strong correlation of molting and appearance of new Hbs in a stage-specific manner suggested hormonal role and its control over $\mathrm{HBb}$ synthesis (Trewitt and Bergtrom, 1981). Subsequently, using radio-isotope based tracing techniques, Vofopoulou-Mandalos and Laufer $(1982,1984)$ demonstrated how ecdysterone and Juvenile hormone regulate $\mathrm{Hb}$ synthesis during larval development of C. thummi. They also suggested that both these hormones could play a role in modulating the expression of $\mathrm{Hb}$ gene.

\section{Cytogenetic features}

Although there have been plenty of cytogenetic studies on various aspects using Chironomus larval salivary gland polytene chromosomes, literature on any cytogenetic studies relevant to chironomid $\mathrm{Hb}$ is almost nil except two seminal studies by Hankeln et al. (1988) and Schmidt et al. (1988). Globin gene cluster from the subspecies C. thummi piger was localized to chromosome II (the chromosomal band position F2b2) by in situ hybridization (Hankeln et al. 1988). The same laboratory embarked on an exploration of distribution of $\mathrm{Hb}$ genes on polytene chromosomal regions of different Chironomus species. Schmidt et al. (1988) investigated 13 Chironomus species and their robust data demonstrated localization of $\mathrm{Hb}$ genes coding for monomeric and dimeric $\mathrm{Hb}$ proteins on chromosome arms $\mathrm{E}$ and $\mathrm{D}$ respectively. These cytogenetic data on the distribution of $\mathrm{Hb}$ genes on polytene chromosomes agreed with the cytological data of Keyl (1962), often used to establish evolutionary relationships among the different Chironomus species.
There has been a long gap in the literature concerning any cytogenetic studies linked with chironomid Hb subsequent to Hankeln et al. (1988) and Schmidt et al. (1988). Much later, my laboratory carried out cytogenetic study in the oriental non-biting midge C. ramosus which has relevance to larval $\mathrm{Hb}$ content as a function of dietary iron content. I used two variant larval populations of $C$. ramosus generated by Babrekar (2009) under differential simulated conditions of providing one and half fold more iron $(\mathrm{Fe})$ containing diet versus low-Fe diet relative to the standard food recipe prescribed by Nath and Godbole (1998). The resultant larval population exhibited concomitant higher and lower $\mathrm{Hb}$ level in larval hemolymph (Babrekar 2009). Interestingly, the two variant group of larval population showed heterochrony with respect to pupal emergence calendar (Tab. 1). One of the cytogenetic hallmarks of prepupal developmental stage of $C$. ramosus is the appearance of Balbiani Ring (BR) at 18C locus of chromosome IV (Fig. 1). I studied the appearance and extent of puffing of $18 \mathrm{C}$ locus in the two developmentally variant larval populations with respect to their Fe-rich versus low-Fe dietary rearing conditions concomitant with high and low Hb level (Tab. 1). The findings showed a cytogenetic correspondence of heterochrony in the developmental timing of metamorphic event as indicated by the cytogenetic marker (onset of BR manifestation). These data warrant further studies to explore involvement of hormonal and molecular events signaling critical levels of $\mathrm{Hb}$ in the larval hemolymph prior to metamorphosis.

Tab. 1. Heterochrony in onset and extent of manifestation of Balbiani Ring (BR) activity of 18C locus of chromosome IV (Reference map: Nath and Godbole, 1997) in two groups of larvae of larvae of Chironomus ramosus, grown either in Iron (Fe) rich or low diet (Babrekar, 2009) possessing high ( $0.8 \pm 0.09 \mathrm{gm} \mathrm{Hb} / \mathrm{gm}$ body weight) and low ( $0.5 \pm 0.04 \mathrm{gm} \mathrm{Hb} / \mathrm{gm}$ body weight) hemoglobin content. Puffing index is estimated from the ratio (mean \pm SD) of chromosomal locus $18 \mathrm{C}$ (which exhibits developmental stage specific expression of BR) width to that of $18 \mathrm{~B}$ locus (which never shows any puffing).

\begin{tabular}{lrc}
\hline Larval age (days post hatching) & $\begin{array}{c}\text { 18C BR puffing index } \\
15\end{array}$ & $\begin{array}{c}\text { Larvae with low Ho level grown with low-Fe diet } \\
\text { Larvae with high Hb level grown with Fe-rich diet }\end{array}$ \\
\hline 16 & $1.00 \pm 0.01$ & $2.00 \pm 0.02$ \\
\hline 17 & $1.00 \pm 0.02$ & $3.30 \pm 0.01$ \\
\hline 18 & $1.00 \pm 0.01$ & $3.75 \pm 0.02$ \\
\hline 19 & $1.75 \pm 0.02$ & $4.25 \pm 0.03$ \\
\hline 20 & $2.00 \pm 0.02$ & $4.00 \pm 0.03$ \\
\hline 21 & $2.00 \pm 0.02$ & Onset of pupation \\
\hline 23 & $3.00 \pm 0.02$ & \\
\hline 24 & $3.25 \pm 0.03$ & \\
\hline 25 & $3.00 \pm 0.01$ &
\end{tabular}




\section{Biochemical features}

Among all the chironomid midges known till date, hemoglobin (also referred to as erythrocruorin in literature available 4-5 decades earlier) from Chironomus thummi thummi has remained as the most studied molecule. Different components of hemoglobin from $C$. thummi thummi (CTT-Hb) revealed many unique features which could be correlated with the structure, function and adaptation (Buse et al., 1979). Pioneering work by $\mathrm{G}$. Braunitzer and his collaborators characterized twelve different isoforms of $\mathrm{Hbs}$ from the hemolymph of C. thummi thummi, abbreviated as CTT as prefix followed by roman numerical representing chromatographic fractions. Amongst these, CTT-III was the first high resolution structure of any invertebrate $\mathrm{Hb}$, which turned out to be the subject of many biochemical, biophysical and molecular biological studies (Green et al., 1998 and references therein). Other studies of Chironomus species of plumosus group revealed presence of sixteen different $\mathrm{Hb}$ fractions (Shobanov 2004).

Hbs of C. thummi exist in the hemolymph in a $\mathrm{pH}$ dependent equilibrium between monomers and dimmers (Braun et al., 1968; Sick et al., 1972). Thomson et al. (1968) demonstrated larval Hbs of C. tentans as exclusively monomeric with a molecular weight of $\sim 15,900$. There has been contradicting views and findings regarding molecular weight of $\mathrm{Hbs}$ of different Chironomus species, including the monomeric versus dimeric forms of $\mathrm{Hbs}$. It started from the initial observation of Svedberg (1934) which was re-estimated by others (Osmulski and Leyko, 1986). Series of findings in C. thummi thummi confirmed subsequently

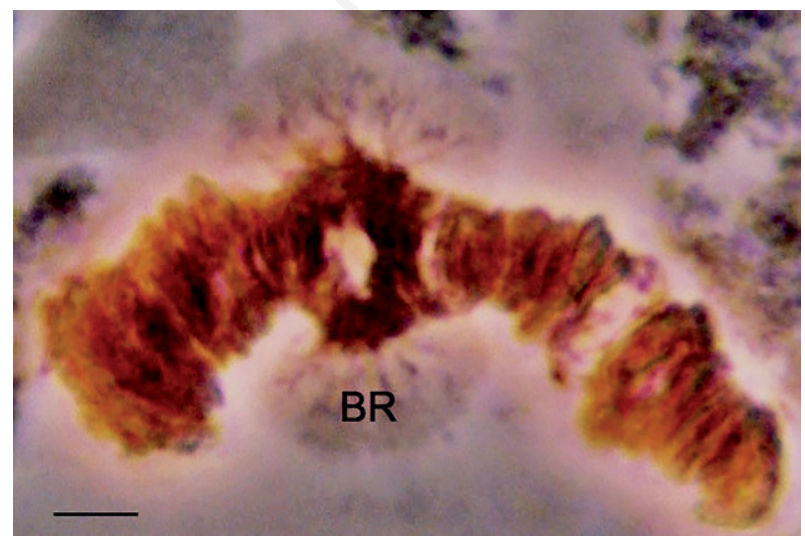

Fig. 1. Representative photomicrograph of chromosome IV from the salivary gland polytene chromosome complements of Chironomus ramosus (Nath and Godbole, 1997) showing a conspicuous Balbiani Ring (BR) at $18 \mathrm{C}$ locus. Scale bar: $10 \mu \mathrm{m}$. that isoforms of electrophoretically different Hbs exist either as monomeric or as dimeric form and maintain a pH dependent equilibrium (Braun et al., 1968; Pfletschinger et al., 1980). Chironomid Hbs can bind oxygen with high affinity $\left(\mathrm{P}_{50}=0.6-1.5\right.$ Torr at $\mathrm{pH} 7$ and $20^{\circ} \mathrm{C}$ ) and in a non-cooperative manner. Under physiological conditions, $\mathrm{O}_{2}$ binding can get modulated by changes in $\mathrm{pH}$ of milieu which is known as Bohr effect. Chironomid Hbs are exceptional for showing absence of cooperativity and an alkaline Bohr effect except for CTT-I (Wollmer et al., 1972; Steffens et al., 1977; Burmester and Hankeln, 2007).

Under physiological $\mathrm{pH}$ condition of around six monomeric and homodimeric $\mathrm{Hb}$ components correspond to molecular weight of about 16,000-17,000 and 32,00034,000 , respectively. Notwithstanding the fact that almost all $\mathrm{Hb}$ related biochemical and biophysical characterization was carried out on different European chironomid midges, the first report of $\mathrm{Hb}$ of any oriental chironomid midge species was reported by Das and Handique (1996). Eleven $\mathrm{Hb}$ components from Indian midge species $C$. ramosus were described which were found to comprise three monomers, seven dimers and one on both monomeric and dimeric forms. This is in contrast with ten and twelve isoforms of $C$. plumosus and $C$. thummi thummi respectively. Many workers in this field developed and refined biochemical procedures of preparation of $\mathrm{Ch}-\mathrm{Hb}$ for experimental and analytical studies. Ruf et al. (1994) published comprehensive methods for preparation and characterization of CTT-Hbs which was standardized by many scientists for quantitative assay of $\mathrm{Ch}-\mathrm{Hbs}$, often with modification (Ronad and Nath, 2017). Besides conventional biochemical studies, an electrophoretic method to obtain $\mathrm{Hb}$ profile using denaturing polyacrylamide gel was shown to be useful for chironomid species identification (Oh et al., 2014). This is a first report of an interdisciplinary approach for a potential application of Chironomus $\mathrm{Hb}$ in taxonomy.

In the literature, three-dimensional structure of deoxy hemoglobin (component III) from Chironomus thummi thummi has remained the only source for a reference structure to carry out biochemical and bioinformatics studies (Gaikwad et al. 2016). From the evolutionary point of view, it is important to note that amino acid in heme binding pockets of $\mathrm{Hb}$ molecules underwent drastic evolutionary diversifications resulting in complete absence of amino acids like isoleucine and glutamine in human $\mathrm{Hb}$ during the course of evolution since the speciation of non-biting chironomid midges (Tab. 2). Such biochemical combined with bioinformatics analyses hold promise for future revelation of many unknown facts of evolutionary transitions of invertebrate $\mathrm{Hb}$ to vertebrate $\mathrm{Hb}$. 


\section{CHIRONOMUS HEMOGLOBIN AND STRESS TOLERANCE}

\section{Hypoxia}

One of the most remarkable ability of chironomid midge larvae has been their tolerance to extreme hypoxic conditions. $\mathrm{Hb}$ and the bright red color of chironomid midge larvae were linked as early as in the $19^{\text {th }}$ century (Rollett, 1861; Lankester, 1872). Miall and Hammond (1900) and Pause (1919) speculated Hb's role in oxygen storage by chironomid larvae. Fox (1955) observed an elevated level of $\mathrm{Hb}$ synthesis in chironomid larvae in poorly aerated water. $\mathrm{Ch}-\mathrm{Hb}$ facilitates absorption of oxygen from the surrounding water at partial oxygen pressures ranging from 10-50 Torr (Redecker and Zebe, 1988; Zebe, 1991). There have been other studies demonstrating how larvae could carry out aerobic metabolism under hypoxic conditions. Concentration of $\mathrm{Hb}$ as a function of increasing oxygen depletion was established in C. riparius by Grazioli et al. (2016) who provided metabolic explanation of Hb's role during anaerobiosis and how $\mathrm{Hb}$ might play a role in short-term oxygen storage.

Kawai et al, (2004) evaluated respiration rates and survival rates of Japanese Chironomus spp. under anoxic conditions and found high $\mathrm{Hb}$ content in chironomids living in lentic environments in contrast to those living in lotic waters. Moreover, survival duration was found longer with increasing respiration rates and $\mathrm{Hb}$ contents. Varying level of $\mathrm{Hb}$ has been reported to depend on the ambient concentration of dissolved oxygen in the laboratory reared tropical Indian species $C$. ramosus using a fabricated hypoxia-inducing device customized for experimentation with chironomid larvae (Ronad and Nath, 2017). They reported that simulated hypoxic conditions of $0.5 \mathrm{ppm}$ of dissolved oxygen could induce a multifold increase in $\mathrm{Hb}$ gene expression as a function of

Tab. 2. Bioinformatics analysis of presence $(+)$ and absence (-) of amino acid residues in the heme pocket lining in hemoglobins of Chironomus thummi thummi (CTT-Hb) [PDB id: 1ECA] and human $(\mathrm{Hu}-\mathrm{Hb})$ [PDB id: 2DN2] (data from Dr. Sangeeta Sawant, Bioinformatics Center, SPPU, Pune, India, personal communication).

\begin{tabular}{lcc} 
Amino acid in heme-binding pockets & CTT-Hb & Hu Hb \\
of Hb molecule & & \\
Isoleucine (Ile) & + & - \\
\hline Tyrosine (Tyr) & - & + \\
\hline Alanine (Ala) & - & + \\
\hline Glutamine (Gln) & + & - \\
\hline Asparagine (Asn) & - & + \\
\hline
\end{tabular}

time of exposure. While finding an evolutionary logistics of chironomid midge's remarkable ability to tolerate extreme hypoxic environment, one needs to find out an explanation of proposition of Burmester et al., (2007) that extracellular $\mathrm{Hbs}$ of chironomid midges originated as an evolutionary derivative of intracellular $\mathrm{Hbs}$ in response to selection pressure of hypoxic environment.

\section{Chemical pollutants/toxicants}

Larval discoloration due to decreased red pigmentation typically associated with $\mathrm{Hb}$ was used as one of the early indicators of heavy metal (e.g., copper) toxicity (Majumdar and Gupta, 2012) in C. ramosus. Gradual loss of red color was also observed by MacDonald et al., (2004) due to perfluorooctane sulfonic acid (a fluorinated surfactant) toxicity. Larvae of $C$. riparius exposed to cadmium showed reduction in total $\mathrm{Hb}$ content (Choi and $\mathrm{Ha}, 2009)$. Other studies on natural population of Glyptotendipes spp and Endochironomus spp. exposed to heavy metal contamination ( $\mathrm{cd}, \mathrm{Pb}, \mathrm{Hg}$, $\mathrm{Cr}, \mathrm{Cu}, \mathrm{Zn}$ ) revealed significant reduction in genetic diversity and variable level of $\mathrm{Hb}$ protein diversity (Jacobs and Marie, 2006). Amongst environmental pollutants/ toxicants many chemical substances are redox-active. Studies carried out by Choi and Roche (2004) in C. riparius suggested auto-oxidation of $\mathrm{Hb}$ in response to such redox-active chemicals. In one of the interesting findings in C. riparius adapted to acid environment suggested remarkable buffering capacity of $\mathrm{Hb}$ in $\mathrm{pH}$ as low as 3.5. This Canadian strain of $C$. riparius possessed twice the content of other strains of same species inhabiting non-acidic environment (Jernelöv et al., 1981).

Chemical-specific $\mathrm{Hb}$ gene expression in $C$. tentans was reported by Lee et al., (2006) while evaluating consequences of larval exposure to pollutants. Interestingly, alkyl phenolic compounds elevated the expression of $\mathrm{Hb}$ gene while pesticides decreased the expression. Extension of similar studies by the same research group revealed that C. riparius globins could exist in both inducible and constitutively expressed forms. Presence of multiple globin isoforms facilitated the organism to adapt to pollutants (Ha and Choi, 2008). They observed downregulation of oxyhemoglobin on exposure to bisphenol $\mathrm{A}$ and chlorpyriphos suggesting its elevated autoxidation to methemoglobin. Similar to hypoxia, oxygen deficiency could be induced chemically by herbicide treatment (e.g. Atrazine) and C. tentans larvae were found to modulate $\mathrm{Hb}$ level by regulating its gene expression at the level of transcription (Anderson et al., 2007). Quite often, due to chemical specific response of $\mathrm{Ch}-\mathrm{Hb}$, many studies remained inconclusive for validating appropriateness of $\mathrm{Hb}$ as bioindicator of all types of pollutants/ toxicants per se (Darville and Whilm, 1984). 


\section{Radiation}

Among earliest reports on radiation tolerance of chironomid midges, cytogenetic findings of Blaylock (1966) seems to be the most noteworthy followed by other studies from Michailova's (Michailova and Petrova, 1994, 2015) and Nath's research group (Datkhile et al., 2009a and cross references citing previous works on radiation induced deformities in Chironomus spp.). Detailed studies on the cellular and molecular basis of gamma radiation tolerance in Indian species of midge C. ramosus were initiated by Nath and his collaborators (Rita Mukhopadhyaya, BARC, Mumbai and Sangeeta Sawant, S.P. Pune University, Pune, India) who established chironomid midges as one of the insect groups tolerant to high doses of gamma radiation (Datkhile et al., 2009a, 2009b, 2011, 2015). Recently the focus of this research group shifted to $\mathrm{Hb}$ of $C$. ramosus larvae subjected to high doses of gamma radiation and a few interesting facts got revealed (Kumar et al., 2017, Gaikwad et al., 2016) which are worth mentioning in this review.

Sensitivity of $\mathrm{Ch}-\mathrm{Hb}$ and human hemoglobin $(\mathrm{Hu}-\mathrm{Hb})$ to gamma radiation (2400 Gy with dose rate of 52.6 $\mathrm{Gy} / \mathrm{min}$ ) was evaluated and a remarkable stability as well as integrity of $\mathrm{Ch}-\mathrm{Hb}$ were observed when compared to $\mathrm{Hu}-$ $\mathrm{Hb}$. Irradiated $\mathrm{Ch}-\mathrm{Hb}$ exhibited a slight decrease in the intensity in UV-visible absorption spectrum without any alteration in Soret peak position at $415 \mathrm{~nm}$, characteristic for $\mathrm{Hbs}$. On the other hand, $\mathrm{Hu}-\mathrm{Hb}$ showed molecular damage and a shift in Soret band when subjected to similar dose of gamma radiation. Unlike $\mathrm{Ch}-\mathrm{Hb}$, additional biophysical analyses indicated relatively higher sensitivity of $\mathrm{Hu}$-hb with reference to heme pocket of $\mathrm{Hb}$ molecules (Gaikwad et al., 2016). This was interesting to note from the evolutionary point of view because $\mathrm{Hu}-\mathrm{Hb}$ represents vertebrate Hbs which underwent little changes since the time of divergence of vertebrates and invertebrates. A sequence and structure-based bioinformatic analysis (Gaikwad et al., 2016 and unpublished data of Sawant and Nath) revealed higher hydrophobicity around heme pockets of $\mathrm{Ch}-\mathrm{Hb}$ when compared to $\mathrm{Hu}-\mathrm{Hb}$. The remarkable resistivity of chironomid midges to adverse environmental conditions in general could be attributed to hydrophobicity of heme pockets of $\mathrm{Ch}-\mathrm{Hb}$ and molecular evolutionary history of this group of insects.

\section{CONCLUSIONS AND FUTURE PERSPECTIVE}

Unlike the vertebrates, Hbs among the invertebrate animals are not ubiquitous. Despite rapid evolutionary divergence, vertebrate $\mathrm{Hb}$ retained structural similarity to greater extent when compared to repertoire of invertebrate Hbs. Much remains to be understood regarding extensive interspecific polymorphism and the presence of large number of isoforms of $\mathrm{Hb}$ which are developmentally regulated during larval phase in chironomid midges. We do not know much about the selective advantage for multiplicity of $\mathrm{Hb}$ loci in Chironomus spp. Perhaps, temporal pattern of developmental stage specific expression of $\mathrm{Hb}$ loci in the larvae provides adaptive fitness in aquatic environments with very low oxygen tensions as well as in the presence of pollutants and toxicants in the ambient water.

Although $\mathrm{Ch}-\mathrm{Hb}$ has been advocated by many as a candidate biomarker for environmental monitoring purpose, one should ensure whether $\mathrm{Ch}-\mathrm{Hb}$ always qualifies to be a 'unique indicator' for any particular stressor. For that matter, can $\mathrm{Ch}-\mathrm{Hb}$ either qualitatively or quantitatively distinguish hypoxia-anoxia related stress response versus consequences due to heavy metal pollution in the same ecosystem? Nevertheless, one needs to be cautious before euphorically proposing $\mathrm{Ch}-\mathrm{Hb}$ as bioindicator of a particular stressor in natural habitats where other stress-inducing variables also prevail. Much remains to be done to monitor synergistic as well as antagonistic impact on the hemoglobin of Chironomus spp. in freshwater ecosystem where the population is subjected to more than one environmental stressors. Presence of large number of $\mathrm{Hb}$ variants in any given species of chironomid midge is also intriguing. Perhaps, this multiplicity of Hbs would be explained in future studies at the functional level with reference to tolerance towards multitude of stressors in the natural habitats of different midge species.

\section{ACKNOWLEDGEMENTS}

I am thankful for the logistic and infrastructural support received from DRDP, DST-PURSE, UPE-II and UGCCAS-III grant at the Department of Zoology, Savitribai Phule Pune University (SPPU). I especially acknowledge the financial support received from the SPPU-Board of College and University Development grant (2016-18).

\section{REFERENCES}

Anderson TD, Jin-Clark Y, Begum K, Starkey SR, Zhu KY, 2007. Gene expression profiling reveals decreased expression of two hemoglobin genes associated with increased consumption of oxygen in Chironomus tentans exposed to atrazine: a possible mechanism for adapting to oxygen deficiency. Aquat. Toxicol. 86:148-156.

Antoine M, Niessing J, 1984. Intron-less glob genes in the insect Chironomus thummi thummi. Nature 310: 795-798.

Armitage PD, Cranston PS, Pinder LCV, 1995. The Chironomidae: The biology and ecology of non-biting midges. Chapman \& Hall, London: 572 pp.

Babrekar AA, 2009. The role of iron in the homeostasis and abiotic stress response in Chironomus ramosus. Ph.D. Thesis, Savitribai Phule Pune University, Pune, India. 
Ballesteros SC, deBarrio M, Baeza ML, Sotes MR, 2006. Allergy to chironomid larvae (red midge larvae) in nonprofessional handlers of fish food. J. Investig. Allergol. Clin. Immunol. 16: 63-68.

Baur X, Aschauer H, Mazur G, Dewair M, Prelicz H, Steigemann W, 1986. Structures, antigenic determinants of some clinically important insect allergens: Chironomid hemoglobins. Science 233:351-354.

Bergtrom G, Laufer H, Rogers R, 1976. Fatbody: A site of hemoglobin synthesis in Chironomus thummi (Diptera). J. Cell Biol. 69: 264-274.

Bernabo, P, Rebecchi L, Jousson O, Martinez-Guitarte JL, Lencioni V, 2011. Thermotolerance and hsp70 heat shock response in the cold-stenothermal chironomid Pseudodiamesa braniekil (NE Italy). Cell Stress Chaperones 16:403-410.

Blaylock BG, 1966. Chromosomal polymorphism in irradiated natural populations of Chironomus. Genetics 53: 131-136.

Braun V, Crichton RR, Braunitzer G, 1968. [Über monomer und dimere Insektenhämoglobine (Chironomus thummi)]. [Article in German]. Hoppe-Seyler's Z. Physiol. Chem. 349:197-210.

Burmester T, Hankeln T, 2007. The respiratory proteins of insects. J. Insect Physiol. 53: 285-294.

Burmester T, Storf J, Hasenjager A, Klawitter S, Hankeln T, 2006. The hemoglobin genes of Drosophila. FEBS J. 273: 468-480.

Buse G, Steffens GJ, Braunitzer G, Steer W, 1979. [Hämoglobine XXV. Hämoglobin (Erythrocruorin) CTTIII aus Chironomus thummi thummi (Diptera). Primärstruktur und Benziehung zu anderen Hämproteinen].[Article in German]. Hoppe-Seyler's Z. Physiol. Chem. 360:89-97.

Choi J, 2004. Biomarkers in environmental monitoring and its application in Chironomus spp., p. 203-215. In: S.K. Hong, J.A. Lee, B.-S. Ihm, A. Farina, Y. Son, K. Eun-Shik and J.C. Choe (eds.), Ecological issues in a changing world. Springer.

Choi J, Ha MH, 2009. Effect of cadmium exposure on the globin protein expression in $4^{\text {th }}$ instar larvae of Chironomus riparius $\mathrm{Mg}$ (Diptera: Chironomidae): an ecotoxicoproteomics approach. Proteomics 9:31-39.

Choi J, Roche H, 2004. Effect of potassium dichromate and fenitrothion on hemoglobins of Chironomus riparius $\mathrm{Mg}$ (Diptera, Chironomidae) larvae: Potential biomarker of environmental biomonitoring. Environ. Monit. Assess. 92:229-239.

Clarke GM, 1993. Fluctuating asymmetry of invertebrate populations as a biological indicator of environmental quality. Environ. Pollut. 82:207-211.

Cranston PS, 1988. Allergens of non-biting midges (Diptera: chironomidae): a systematic survey of chironomid haemoglobins. Med. Vet. Entomol. 2:117-127.

Darville RG, Wilhm JL, 1984. The effect of naphthalene on oxygen consumption and hemoglobin concentration in Chironomus attenuates and on oxygen consumption and life cycle of Tanytarsus dissimilis. Environ. Toxicol. Chem. 3:135-141.

Das R, Handique R, 1996. Hemoglobin in Chironomus ramosus (Insecta, Diptera): an electrophoretic study of polymorphism, developmental sequence and interspecific relationship. Hydrobiologia 318:43-50.

Datkhile KD, Dongre TK, Mukhopadhyaya R, Nath BB, 2009a. Gamma radiation tolerance of a tropical species of midge,
Chironomus ramosus Chaudhuri (Diptera: Chironomidae). Int. J. Radiat. Biol. 85: 1-9.

Datkhile KD, Gaikwad P, Mukhopadhyaya R, Ghaskadbi SS, Nath BB, 2015. Chironomus ramosus larvae exhibit DNA damage control in response to gamma radiation. Int. J. Radiat. Biol. 91:742-748.

Datkhile KD, Mukhopadhyaya R, Dongre TK, Nath BB, 2009b. Increased level of superoxide dismutase (SOD) activity in larvae of Chironomus ramosus (Diptera: Chironomidae) subjected to ionizing radiation. Comp. Biochem. Physiol. 149:500-506.

Datkhile KD, Mukhopadhyaya R, Dongre TK, Nath BB, 2011. Hsp70 expression in Chironomus ramosus exposed to gamma radiation. Int. J. Radiat. Biol. 87:213-221.

Dias V, Vasseur C, Bonzom JM, 2008. Exposure of Chironomus riparius larvae to uranium: Effects on survival, developmental time, growth and mouthpart deformities. Chemosphere 71:574-581.

English DS, 1969. Ontogenic changes in hemoglobin synthesis of two strains of Chironomus tentans. J. Embryol. Exp. Morph. 22: 465-476.

Ferrington LC Jr, 2008. Global diversity of non-biting midges (Chironomidae: Insecta-Diptera) in freshwater. Hydrobiologia 595:447-455.

Fox HM, 1949. On chlorocruorin and haemoglobin. P. Roy. Soc. B.-Biol. Sci. 136:378-388.

Gaikwad PS, Panicker L, Mohole M, Sawant S, Mukhopadhyaya R, Nath BB, 2016. Differential sensitivity of Chironomus and human hemoglobin to gamma radiation. Biochem. Biophys. Res. Commun. 476: 371-378.

Goodman M, Pedwaydon J, Czelusniak J, Suzuki T, Gotoh T, Moens L, Shishikura F, Walz D, Vinogradov S, 1988. An evolutionary tree for invertebrate globin sequences. J. Mol. Evol. 27:236-249.

Grazioli V, Rossaro B, Parenti P, Giacchini R, Lencioni V, 2016. Hypoxia and anoxic effects on alcohol dehydrogenase activity and hemoglobin content in Chironomus riparius Meigen, 1804. J. Limnol. 75:347-354. Doi: 10.4081/jlimnol.2016.1377

Green BN, Kuchumov AR, Hankeln T, Schmidt ER, Bergtrom G, Vinogradov SN, 1998. An electrospray ionization mass spectrometric study of the extracellular hemoglobins from Chironomus thummi thummi. Biochim. Biophys. Acta 1383:143-150.

Gruhl MC, Scherbik SV, Aimanova KG, Blinov A, Diez JL, Bergtrom G, 2000. Insect globin gene polymorphisms: intronic minisatellites and a retroposon interrupting exon 1 of homologous globin genes in Chironomus (Diptera). Gene 251:153-163.

Ha HM, Choi J, 2008. Effects of environmental contaminants on hemoglobin of larvae of aquatic midge, Chironomus riparius (Diptera: Chironomidae): A potential biomarker for ecotoxicity monitoring. Chemosphere 71:1928-1936.

Hamalainen H, 1999, Critical appraisal of the indexes of Chironomid larval deformities and their use in bioindication. Annal. Zool. Fenn. 36:179-186.

Hankeln T, Amid C, Weich B, Niessing J, Schmidt ER, 1998. Molecular evolution of the globin gene cluster $\mathrm{E}$ in two distantly related midges, Chironomus pallidivittatus and $C$. thummi thummi. J. Mol. Evol. 46: 589-601.

Hankeln T, Friedl H, Ebersberger T, Martin J, Schmidt ER, 1997. 
A variable inron distribution in globin genes of Chironomus: Evidence for recent intron gain. Gene 205:151-160.

Hankeln T, Rozynek P, Schmidt ER, 1988. The nucleotide sequence and in situ localization of a

gene for dimeric haemoglobin from the midge Chironomus thummi piger. Gene 64: 297-304.

Hardison R, 1998. Hemoglobins from Bacteria to Man: Evolution of different patterns of gene expression. J. Exptl. Biol. 201:1099-1117.

Ingersoll C, Nelson MK, 1990. Testing sediment toxicity with Hyalella azteca (amphipod) and Chironomus riparius (Diptera), p. 93-110. In: W. Landis and W.V. Sschalie (eds.), Aquatic Toxicology and risk assessment. American Society of testing and materials, Philadelphia.

Jacobs DC, Marie L, 2006. Chironomid hemoglobin genetic diversity as an indicator of the New Jersey Hackensack Meadowlands wetland health. Seton Hall University Dissertations and Theses (ETDs).Available from: http://scholarship.shu.edu/disserttions/2380

Jarial MS, 1988. Fine structure of the Malpighian tubules of Chironomus larva in relations to glycogen storage and fate of hemoglobin. Tissue Cell 20:355-380.

Jernelöv A, Nagell B, Svenson A, 1981. Adaptation to an acid environment in Chironomus riparius (Diptera Chironomidae) from Smoking Hills, NWT, Canada. Ecography 4:116-119.

Karouna-Reiner NK, Zehr JP, 1999. Ecological implications of molecular biomarkers: assaying sub-lethal stress in the midge Chironommus tentans using heat shock protein 70 (Hsp70) expression. Hydrobiologia 401:255-264.

Kawai K, Hashimoto M, Imagayashi H, 2004. Environmental factors affecting the quality and quantity of hemoglobin in Chironomus larvae (Diptera: Chironomidae). Med. Entomol. Zool. 55: 281-287.

Keyl HG, 1962. [Chromosomen evolution bei Chironomus. II. Chromosome numbauten und phylogenetische bezienhungender Arten].[Article in German]. Chromosoma 13:464-514.

Kumar A, Shetake NG, Ali M, Balla S, Yadav R., Pandey BN, Mishra KP, 2017. Recent advances in radiation research for human health and environment. J. Radiat. Cancer Res. 8:186-191.

Lankester ER, 1872. A contribution to the knowledge of hemoglobin. P. R. Soc. London 21:70-81.

Lee SM, Lee SB, Park CH, Choi J, 2006. Expression of heat shock protein and hemoglobin gene in Chironomus tentans (Dipteraa, Chironomidae) larvae exposed to various environmental pollutants: A potential biomarker of freshwater monitoring. Chemosphere 65:1074-1081.

Lencioni V, Grazioli V, Rossaro B, Bernabo P, 2016. Transcriptional profiling induced by pesticides employed in organic agriculture in a wild population of Chironomus riparius under laboratory conditions. Sci. Total Environ. 557-558:183-191.

MacDonald MM, Warne AL, Stock NL, Maburg SA, Solomon KR, Sibley PK, 2004. Toxicity of perfluorooctane sulfonic acid and perfluorooctanoic acid to Chironomus tentans. Environ. Toxicol. Chem. 23:2116-2123.

Majumdar TN, Gupta A, 2012. Acute and chronic toxicity of copper on aquatic insect Chironomus ramosus from Assam, India. J. Environ. Biol. 33:139-142.

Manwell C, 1966. Starch gel electrophoresis of the multiple haemoglobins of small and large larval Chironomus - a developmental haemoglobin sequence in an invertebrate. J. Embryol. Exp. Morph. 16:259-270.

Martin J, 1996. An annotated bibliography of the cytogenetics of the Chironomidae (Diptera). Occ. Pap. Syst. Ent. 10:1-209.

Miall LC, Hammond AR, 1900. The structure and life history of the Harlequin fly (Chironomus). Clarendon Press, Oxford.

Michailova P, Petrova N, 1994. Cytogenetic characterization of Chironomus balatonicus Devai. Wulker, Schooll (Diptera: Chironomidae) from Chernobyl region. Cytobios 79:15-29.

Michailova P, Petrova N, 2015. Bioindicator potential of cytogenetic variability in polytene chromosomes of chironomids (Diptera: Chironomidae) to assess environmental pollution. Cytol. Genet. 49:262-269.

Michailova P, Sella G, Petrova N, 2011. Chironomids (Diptera) and their salivary gland chromosomes as indicators of tracemetal genotoxicity. Ital. J. Zool. 79:218-230.

Michailova P, Sella G, Petrova N, 2012. Polytene chromosomes of Chironomidae (Diptera) as a bioassay of trace-metalinduced genome instability. Fauna Norvegia 31:227-234.

Morales M, Planello R, Martinez-Paz P, Herrero O, Cortes E, Martinez-Guitarte JL, Morcillo G, 2011. Characterization of Hsp70 gene in Chironomus riparius: expression in response in endocrine disrupting pollutants as a marker of ecotoxicological stress. Comp. Biochem. Physiol. C. Toxicol. Pharmacol. 153:150-158.

Nath BB, Godbole NN, 1997. Chromosomal characterization of a tropical midge. Cytobios 91:25-31.

Nath BB, Godbole NN, 1998. Technique for mass rearing of Indian Chironomus species. Studia Dipterologica 5:187-193.

Nath BB, Lakhotia SC, 1989. Heat shock response in a tropical Chironomus: Seasonal variation in response and the effect of developmental stage and tissue type on heat shock protein synthesis. Genome 32:676-686.

Oh JT, Epler JH, Bentivegna CS, 2014. A rapid method of species identification of wild chironomids (Diptera: Chironomidae) via electrophoresis of hemoglobin proteins in sodium dodecyl sulfate polyacrylamide gel (SDS-PAGE). Bull. Entommol. Res. 104:639-651.

Oliver DR,1971. Life history of Chironomidae. Ann. Rev. Entomol. 16:211-230.

Osmulski PA, Leyko W, 1986. Structure, function and physiological role of Chironomus haemoglobin. Comp. Biochem. Phys. B 85:701-722.

Pause J, 1919. [Beiträge zur Bioligie und physiologie der larve von Chironomus gregarious].[Article in Germann]. Zool. Zbl. 36:339-452.

Pesce A, Nardini M, Dewilde S, Hoogewijs D, Ascenzi P, Moens L, Bolognesi M, 2005. Modulation of oxygen binding to insect hemoglobins: The structure of hemoglobin from the botfly Gasterophilus intestinalis. Protein Sci. 14:3057-3063.

Pfletschinger J, Plagens H, Braunitzer G, 1980. The primary structure of the monomeric hemoglobin (Erythocuorin) component of CTTIV of Chironomus thummi thummi (Insecta, Diptera). Z. Naturforsch 35:840-843.

Pinder LCV, 1986. Biology of freshwater Chironomidae. Ann. Rev. Entomol. 37:1-23.

Redecker B, Zebe E, 1988. Anaerobic metabolism in aquatic insect larvae: studies on Chironomus thummi and culex pipiens. J. Comp. Physiol. B. 158:307-315. 
Rollett A, 1861. [Zur Kenntnis der Verbreitung des Hämatins]. [Article in German]. Sitzungsberichte der kaiserlichen Akademie der Wissenschaften zu Wien 44:615-630.

Ronad A, Nath BB, 2017. Design and fabrication of a hypoxiainducing chamber for simulation studies in environmental biomonitoring using Chironomus larvae. Res. Rev. J. Zool. Sci. 5:45-51.

Ruf HH, Altemuller AG, Gersonde K, 1994. Preparation and characterization of insect hemoglobins from Chironomus thummi thummi. Methods in Enzymol. 231:95-111.

Schin K, Poluhowich JJ, Gamo T, Laufer H, 1974. Degradation of hemoglobin in Chironomus during metamorphosis. J. Insect. Physiol. 20:561-571.

Schmidt ER, Keyl HG, Hankeln T, 1988. In situ localization of two hemoglobin gene clusters in the chromosomes of species of Chironomus. Chromosoma 96:353-359.

Shobanov NA, 2004. Heterogeneity and heterofunctionality of hemoglobins in bloodworms (Diptera: Chironomidae). J. Evol. Biochem. Physiol. 40:392-397.

Sick H, Gersonde K, Thompson JC, Maurer W, Haar W, Ruterjans H, 1972. The Bohr proton binding site in a monomeric haemoglobin: a nuclear magnetic resonance study. Eur. J. Biochem. 29:217-223.

Steffens G, Buse G, Wollmer A, 1977. Ligand-dependent Bohr effect of Chironomus hemoglobins. FEBS J. 72:201-206.

Svedberg T, Erikson-Quensel JB, 1934. The molecular weight of erythrocuorin. J. Am. Chem. Soc. 56:1700-1706.

Terwillinger RC, 1980. Structures of invertebrate hemoglobins. Amer. Zool. 20:53-67.

Thompson P, Bleecker W, English DS, 1968. Molecular size and subunit structure of the hemoglobins of Chironomus tentans. J. Biol. Chem. 243:4463-4467.

Thompson PE, English DS, 1966. Multiplicity of hemoglobins in the genus Chironomus (Tendipes). Science 152:75-76.

Thorat LJ,Oulkar D, Banerjee K, Gaikwad S, Nath BB, 2017. High throughput mass spectrometry analysis revealed a role for glucosamine in potentiating recovery following desiccation stress in Chironomus. Sci. Rep. 7:3659. doi: 10.1038/s41598-017-03572-5

Trewitt PM, Bergtrom G, 1981. Immunological characterization of the haemoglobins of Chironomus thummi. Insect Biochem. 11:635-644.

Vafopoulou-Mandalos X, Laufer H, 1982. The ontogeny of multiple hemoglobins in Chironomus thummi (Diptera): The effects of a compound with juvenile hormone activity. Dev. Biol. 92:135-143.

Vafopoulou-Mandalos X, Laufer H, 1983. Tissue specificity of hemoglobin synthesis: Localization of heme synthesis in the subepidermal fat body of Chironomus thummi (Diptera). Arch. Insect Biochem. Physiol. 1:191-197.

Vafopoulou-Mandalos X, Laufer H, 1984. Regulation of hemoglobin synthesis by ecdysterone and juvenile hormone during development of Chironomus thummi (Diptera). Differentiation 27:94-105.

Vinogradov SN, 1985. The structure of invertebrate extracellular hemoglobins (erythrocruorins and chlorocruorins). Comp. Biochem. Phys. B. 82:1-15.

Vinogradov SN, Hoogewijs D, Bailly X, Arredonto-Peter R, Guertin M, Gough J, Dewilde S, Moens L, Vanfleteren JR, 2005. Three globin lineages belonging to two structural classes in genomes from the three kingdoms of life. P. Natl. Acad. Sci. USA 102:11385-11389.

Weber RE, Vinogradov SN, 2011. Nonvertebrate hemoglobins: Functions and molecular adaptations. Physiol. Rev. 81:569628.

Wollmer A, Buse G, Sick H, Gersonde K, 1972. A myoglobintype hemoglobin of Chironomus thummi thummi. Eur. J. Biochem. 24:547-552.

Zebe E, 1991. In vivo studies on the function of hemoglobin in the larvae of Chironomus thummi (Insect, Diptera). Comp. Biochem. Phys. A 99:525-529. 